\title{
Problems and Strategies in Accounting Information Management under the Background of Big Data
}

\author{
Xu Na \\ Zaozhuang University, Shandong Zaozhuang, China, 277160
}

Keywords: accounting information management; information construction; capital operation; regulatory system;

Abstract: Accounting information management is a part of the daily operation of the enterprise and the main basis for the decision-making and business strategy of the enterprise. To this end, the problems and strategies of accounting information management are studied under the background of big data. The accounting information management under the background of big data has problems such as internal supervision system, authenticity of financial information, effectiveness of capital operation and timeliness of accounting information. According to the problems existing in accounting information management, this paper proposes a financial information management strategy to improve the professional quality of financial personnel, the authenticity of financial information and strengthen the financial information supervision system.

\section{Introduction}

Accounting information management plays a major role in the daily life of enterprises and is an indispensable part of enterprise management. The management of accounting information under the background of big data has gradually changed from the traditional mode to the information management mode. A scientific and rational financial information management system is crucial to the future development of the company. A sound financial information management system can improve the level of financial information management of enterprises, and can also strive for economic benefits for enterprises. In the fierce market competition, enterprises must continue to enhance the core competitiveness of enterprises in order to have a place in the market. At present, there are many shortcomings in the management of corporate accounting information. The lack of a sound management system and systematic management method is the main reason why companies cannot improve their core competitiveness. Especially in the quality of accounting information management, it is necessary to adjust the defects and loopholes in the management process, and lay a good foundation for comprehensively improving the competitiveness and positive benefits of enterprises ${ }^{[1]}$. 


\section{Problems in accounting information management}

\subsection{Safety of the regulatory system}

The lack of a strong internal supervision system for accounting information management under the background of big data is a prominent problem in the management of corporate accounting information. The lack of management of the internal regulatory system is the main reason for the loss of financial information and low utilization. The lack of a managed internal management system will result in a situation in which corporate funds are broken and economic benefits are low. Long-term development will inevitably affect the financial stability and healthy development of enterprises ${ }^{[2]}$.

The computer information technology under the background of big data has been continuously improved, which has provided powerful conditions for the management of enterprise accounting information and transformed the traditional information management mode. However, the computer has easy-to-access and easy-to-modify features, which will have a great impact on the financial information management of the enterprise. The management of accounting information that lacks authenticity and security is easily hacked or modified by hackers, which affects the feasibility of accounting information to a certain extent. Although computer technology can improve the efficiency of accounting information management, it lacks confidentiality and security. The falsification and disclosure of accounting information for the accounting management system will not only cripple the internal system of the enterprise, but also pose a great threat to the security of corporate accounting information ${ }^{[3]}$.

\subsection{Authenticity of financial information}

The loss of data caused by human factors is a problem that cannot be ignored in the management of accounting information. The professional quality of accounting personnel and the management of accounting information are interrelated. Many financial personnel of the company modify the accounting information for their own personal interests, and many professional low-quality staff are engaged in this work. Low-quality staff can not meet the requirements of accounting information management work, and is easily tempted by interests, which will bring important impact and serious losses to accounting information management work ${ }^{[4]}$.

\subsection{Effectiveness of capital operations}

The operation of funds is the basic condition for ensuring the healthy development of the whole enterprise. As an important part of accounting information management, funds should strengthen the system of fund management, otherwise it will affect the normal business activities of enterprises. At present, enterprises lack management and attention to funds. They only show financial information management work in financial consolidation, and lack of effective management is the main reason for enterprises to stagnate. In the process of actual management, the amount of funds will directly affect the normal work of enterprises, and enterprises cannot ignore the importance of capital operation for future development.

\subsection{Timeliness of accounting information}

The lack of timeliness of corporate accounting information at this stage will not only affect the normal operation of enterprises, but also affect the competition of enterprises in the market. In a fierce market competition environment, if the company can't keep up with the pace of the market 
economy, it will have serious consequences. Accounting information management is closely related to the future development of the company, and it is also the main basis for corporate decisionmaking and business strategy. It takes a certain amount of time to process corporate accounting information. Especially for companies with long network business fronts, the timeliness of accounting information is related to the economic benefits of enterprises. If there are mistakes, it will cause hundreds of millions of business balances. The proficiency and innovation ability of financial personnel in accounting information management work will directly affect the timeliness of accounting information. Financial management personnel who do not have professional qualities will not only cause waste of information processing, but also affect the economic waste of the enterprise and cause waste of time ${ }^{[5]}$.

\section{Accounting information management strategy}

\subsection{Improve the professional quality of financial personnel}

In the management of accounting information, the professional quality of financial personnel will directly affect the progress of the implementation of financial information management, enterprises should pay attention to the professional quality of financial personnel. Human factors are the main reason for the lack of authenticity of financial information. Therefore, enterprises should focus on solving the professional quality problems of financial personnel. It is necessary to ensure the effective implementation of corporate financial management. In the process of recruitment, enterprises should give priority to talents with professional qualifications and professional certificates. At the same time, enterprises should organize training on a regular basis and combine talent development with the state of enterprise development. A scientific and rational talent training program can improve the quality of accounting information management. The accounting information management training plan is as follows.

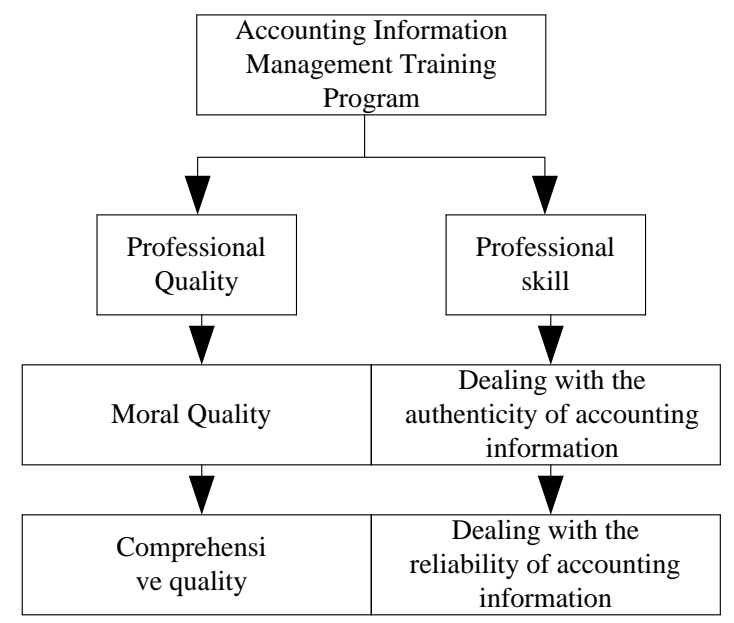

Figure 1 Accounting information management training program

Figure 1 is a financial information management training program. First, companies must select talents suitable for accounting information management based on their own development. Second, training content should be arranged according to company requirements. The training content should be based on the skills to enhance the financial staff's professional skills and efficient processing of financial information. It is necessary to develop professional training programs for employees on a regular basis to improve the professional quality and moral cultivation of financial 
personnel. For financial personnel, the most important thing is the moral quality. They can't modify the content of financial information for personal gain. In the process of training, it is necessary to understand the situation of employees' mastery of professional skills and ensure the training of scientific systems. The work experience and work ability of financial personnel will directly affect the future decision-making and development direction of the enterprise. In the process of training, it is necessary to ensure that the quality of financial personnel is up to standard, otherwise it will affect the level and quality of financial information management. Finally, in the talent management, it is necessary to develop a sound supervision and management system to prevent financial management personnel from modifying the contents of financial information without authorization. The supervision and management system is as follows.

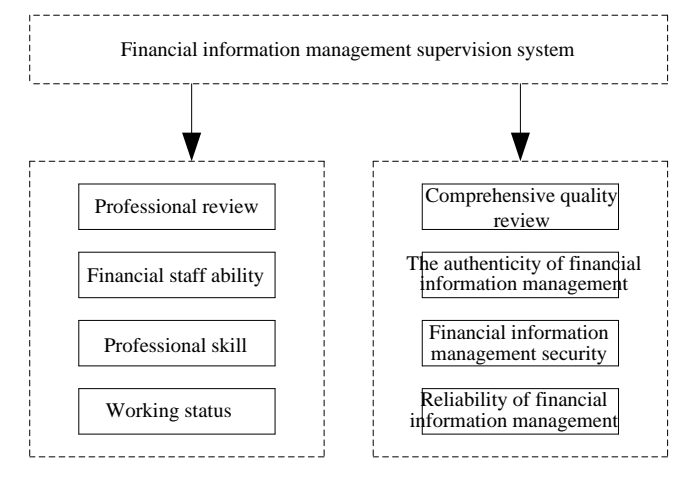

Figure 2 Supervision and management system

Figure 2 is a supervisory management system constructed in accordance with the accounting information management system. The supervisory management system includes professional audits and comprehensive quality audits of financial personnel. Professional quality audits include financial staff abilities, professional skills and work status. The comprehensive quality audit includes the authenticity, rigor and safety of financial personnel in handling financial information. The supervisory management system is used to audit financial personnel, monitor the attitude of the work and the rigor of handling financial information. A complete supervision and management system can improve the level of financial information management of enterprises, and can also meet the needs of enterprises in the current stage for future development ${ }^{[6]}$.

\subsection{Improve the authenticity of financial information}

The most important aspect of enterprise financial information management is authenticity. The complete financial information management system can not only improve the authenticity of financial information, but also ensure the effective operation of corporate funds. For the future development of enterprises, accounting for operating costs and collating financial information is an important guarantee for controlling costs and managing funds. Before investing, companies will make accurate budgets based on the state of financial information to ensure that the flow of funds is within the controllable budget. It can be seen that the authenticity of financial information is of great importance to the stable development of enterprises. Only by strengthening the financial information management system can enterprises improve the authenticity of accounting information and ensure that corporate funds receive effective benefits within the controllable range. The regulation of funds and the performance appraisal of employees are the key needs to be reviewed in the management of accounting information. Only by improving the quality of financial information management can the authenticity of accounting information be improved ${ }^{[7]}$. 


\subsection{Strengthen the supervision system of accounting information}

Enterprises should set up a special financial audit department according to the management structure, and regularly review financial information to ensure the authenticity and reliability of financial information. At the same time, enterprises must vigorously implement the reward and punishment system, reward outstanding employees, stimulate the enthusiasm of employees, and strengthen the financial personnel's ideological understanding of financial information management. In the context of big data, there are high requirements for the authenticity and security of financial information. Enterprises should strengthen the construction of financial information management, adopt scientific and rational information construction methods, improve the competitiveness of enterprises in the market, and lay a perfect foundation for future enterprise development ${ }^{[8]}$.

\section{Conclusion}

Financial information management is of vital importance to the development of enterprises. Enterprises must strengthen the information construction of accounting information management and master the operation of accounting information management. There are many problems in the management of accounting information under the background of big data. Enterprises should pay attention to the management of financial information, improve the current situation of financial information management in response to problems in the management process, and ensure the longterm stable development of enterprises.

\section{References}

[1] Tang Dapeng, Sun Xiaotong, Wang Lulu. Optimization of Financial Management Mode of Administrative Institutions from the Perspective of Internal Control [J]. Finance and Accounting, 2017(2): 62-64.

[2] Zhang Xueping, Xи Kai. Research on the Status Quo of Accounting Management Service Informationization from the Perspective of "Internet +"_-Taking Shaanxi Accounting Management Service as an Example[J]. Friends of Accounting, 2017.12(6):1129-1133.

[3] Gong Dagang. The Influence of Accounting Management on Enterprise Decision-making-Comment on the Basis of Accounting Enterprise Decision-making (Management Accounting Volume) (17th Edition of the original book) [J]. Enterprise Management, 2018.23(8).2365-2548.

[4] Zheng Guohong, Huang Yanni. Enterprise Heterogeneity, Corporate Governance Structure and Accounting Information Quality_-Based on the Empirical Data of Listed Companies in China[J]. Communication of Finance and Accounting, 2017.23(6). 265-286.

[5] Wei Linxin, Huang Guoliang, Zhang Min. Research on the Relationship between Managers' Risk Preference and Accounting Information Transparency - Based on the Perspective of Enterprise Growth[J]. Communication of Finance and Accounting, 2017.25(25). 2355-2894.

[6] He Nina. Construction of Accounting Information System Based on REAL Mode in Supply Chain Environment [J]. Communication of Finance and Accounting, 2018.14(13).252-289.

[7] Sun Yufu, Liu Meiling. Technology Application and Accounting Transformation and Upgrade in the Age of "Internet +" - - A Summary of the Main Points of the 15th National Accounting Informationization Annual Conference [J]. Accounting Research, 2017.23(2): 845-895.

[8] Xu Guangyu. Study on Efficiency Control of Network Dynamic Data Communication under Big Data Analysis [J]. Computer Simulation, 2018, 35(08): 140-143+169. 